\title{
Between Prophecy and Its Realisation. A Reading of Lk 1-2 and Acts 2-3 as a Fulfilment of the Isaianic Narrative
}

\author{
Med prerokbo in njenim uresničenjem. Branje \\ Lk 1-2 in Apd 2-3 kot uresničitev Izaijeve pripovedi
}

\begin{abstract}
The article shows graduality of the parting of the ways between Jewish and Christian tradition by underlining some textual evidence from the Lukan corpus that shows how Luke uses Jewish Scriptures with special regard to Isaiah. The article provides a basic overview of a few topics that point to the continuity with the Jewish Scriptures, and exposes some textual evidence that shows how Luke, in his two-volume work (Lk 1-2; Acts 2-3), adopts Isaiah's text in order to demonstrate that God restores his people with the inclusion of the Gentiles.
\end{abstract}

Key Words: nascent Church, intertextuality, Lukan corpus, Jewish-Christian tradition

Izvleček: Članek prikazuje postopnost ločevanja poti med judovsko in krščansko tradicijo, tako da podčrta nekaj besedilnih dokazov iz korpusa Lukan, ki kažejo, kako Luka uporablja judouske spise s posebnim ozirom na Izaija. Članek podaja osnouni pregled nekaj tem, ki kažejo na kontinuiteto z judovskimi spisi, in izpostavlja nekaj besedilnih dokazov, ki kažejo, kako Luka v svojem dvodelnem literarnem opusu (Lk 1-2; Apd 2-3) sprejema Izaijevo besedilo, da bi dokazal, da Bog obnavlja svoje ljudstvo z vključitvijo poganov.

Ključne besede: nastajajoča Cerkev, medbesedilnost, korpus Lukan, judovsko-krščanska tradicija

\section{Introduction}

When I was studying in Jerusalem, I met a Benedictine Monk from Poland who had had some Jewish friends from his youth. He told us an anecdote of one Sabbath feast experience with one of his Jewish friends, a local Jewish family. Before the beginning of Sabbath, they had forgotten to switch on the air-conditioning; thus, they were sweltering in the summer 
heat. When he came to pay them a visit, he put the air-conditioning on for them. He thought they would thank him for this service, yet, as he ironically complained about not receiving an acknowledgment, they told him that he should thank them instead for letting him participate in their Sabbath feast.

Here I do not intend to explore the laws concerning Sabbath nor search for the values that these friends might have embraced together. Instead I will examine the parting of the ways between Jewish and Christian tradition not in terms of a static, temporally-fixed point of discrepancy, but rather, as Daniel Boyarin $(2003,72-78)$ proposes, as a multi-layered dynamic process which can be evidenced through elements of continuity and discontinuity present in Luke's two-volume work.

In this article I would like to underline some textual evidence from the Lukan corpus that shows how Luke uses Jewish Scriptures with special regard to Isaiah. First, I would like to give a basic overview of a few topics that point to the continuity with the Jewish Scriptures. Second, I would like to expose some textual evidence that shows how Luke, in his two-volume work (Lk 1-2; Acts 2-3), adopts Isaiah's text in order to demonstrate that God restores his people with the inclusion of the Gentiles.

\section{A general overview}

First, I will look at some themes that Luke uses in his literary composition, i.e. themes that are pertinent with regard to the relationship between the people of Israel and the nascent community of Jesus' believers. This general overview showing how Luke draws from the Jewish Scriptural legacy is an important cumulative confirmation of the continuity of salvation history within the nascent community.

\subsection{Messianic expectations as a historical background}

The Lukan text resonates with some parts of the Jewish Scriptures dating to the time of the exilic and Hellenistic period that show hope of salvation and the arrival of God's eternal kingdom. 


\section{(1) Expectations of salvation}

Isa 42,1: Israel [is my chosen], my soul has accepted him.

Lk 2,25: [Simeon] waiting for the consolation of Israel

Lk 2,38: [Anna] was speaking of Him to all those who were looking for the redemption of Jerusalem.

Lk 3,15: As the people were in expectation, and all were questioning in their hearts concerning John, whether he might be the Christ.

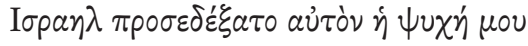

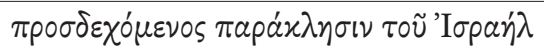

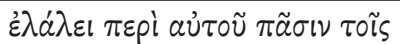

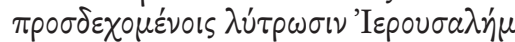

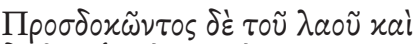

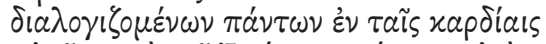

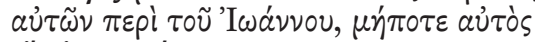

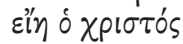

\section{(2) The arrival of the everlasting kingdom}

Dan 3,33: His kingdom is an everlasting kingdom.

Lk 1,33: He will reign over the house of Jacob forever; and His kingdom will have no end.

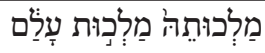

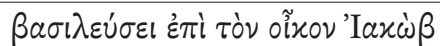

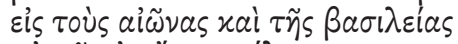

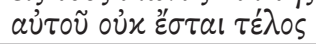

\section{(3) The elements of the Messianic expectations}

Isa 9,6: For unto us a child is born

Lk 2,11: »For unto you is born this day in the city of David a Saviour, who is Christ the Lord."

Isa 61,1: The Spirit of the Lord is upon me,

because he has anointed me.

Lk 4,18: The Spirit of the Lord is upon me,

because he anointed me.

Lk 9,20: [Peter] answering said "The Christ of God."

Acts 5,36-37: For before these days Theudas rose up, claiming to be somebody [...] After him Judas the Galilean rose up in the days of the census and drew away some of the people after him. He too perished, and all who followed him were scattered.

Acts 21,38: "Are you not the Egyptian, then, who recently stirred up a revolt and led the four thousand men of the Assassins out into the wilderness?"

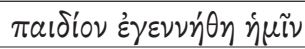

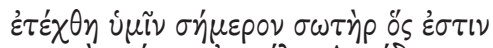

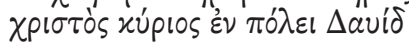

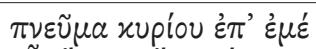

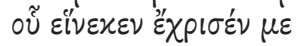

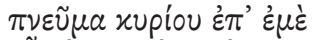

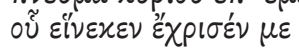

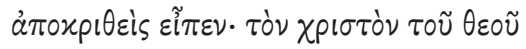

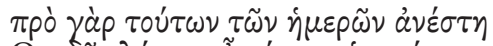

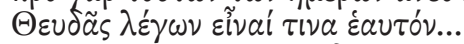

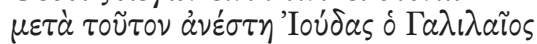

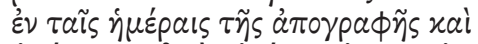

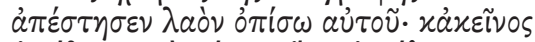

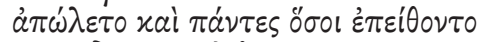

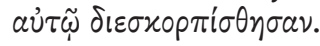

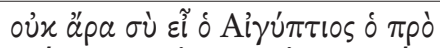
$\tau \circ u ́ \tau \omega \nu \tau \tilde{\omega} \nu \dot{\eta} \mu \varepsilon \rho \tilde{\omega} \nu$ aे $\alpha \sigma \tau \alpha \tau \omega \dot{\omega} \sigma \alpha \varsigma$

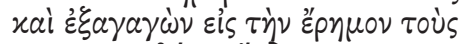

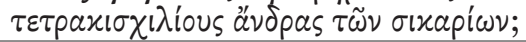




\subsection{Socio-historical analogy}

A similar testimony to Messianic expectations could be found in a socio-religious community of the same period; namely, the Qumran community. Their texts show the same source of inspiration (i.e. Scriptures of Israel) and moreover, also some literary correspondence. Here I would like to point out three thematic instances of correspondence which refer back to Isaiah and which will later be found in Luke. These three topics are found in the Qumran Rule of Community text:

\section{(1) Metaphors of the chosen ones:}

a plant and a costly stone

\begin{tabular}{|c|c|c|}
\hline $1 \mathrm{QS} 8,5$ & An everlasting plantation & למטעת עולצם \\
\hline Isa 60,21 & the branch of his [My] planting & 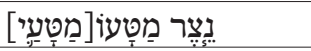 \\
\hline Isa 61,3 & the planting of the LORD & 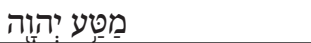 \\
\hline $1 \mathrm{QS} 8,7$ & $\begin{array}{l}\text { the precious cornerstone } \\
\text { costly cornerstone }\end{array}$ & פנת יקר \\
\hline Isa 28,16 & $\begin{array}{l}\text { the stone [cast aside of you } \\
\text { builders] }\end{array}$ & 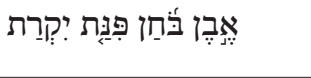 \\
\hline Acts 4,11 & $\begin{array}{l}\text { which is become the head of the } \\
\text { corner }\end{array}$ & 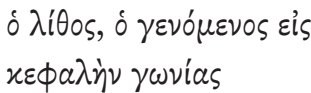 \\
\hline
\end{tabular}

(2) Separation for the sanctity of life:

the retreat into the desert thus to prepare the way for the Lord

\begin{tabular}{|c|c|c|}
\hline 1QS 8,20 & the people of perfect holiness & אנשי התמים קודש \\
\hline 1 QS 9,19-20 & $\begin{array}{l}\text { This is the time for the } \\
\text { preparation of the way into the } \\
\text { wilderness. }\end{array}$ & עת פנות הדרך למדבר \\
\hline Isa 40,3 & $\begin{array}{l}\text { The voice cries: In the } \\
\text { wilderness prepare the way } \\
\text { of the LORD. }\end{array}$ & 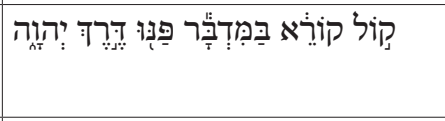 \\
\hline Acts 9,2 & $\begin{array}{l}\text { [Saul] asked for letters from him } \\
\text { to the synagogues at Damascus, } \\
\text { so that if he found any } \\
\text { belonging to the Way. }\end{array}$ & 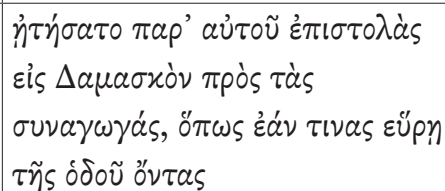 \\
\hline
\end{tabular}

\section{(3) Unity as criterion for the life of community:}

the "men of the community"

\begin{tabular}{|c|c|c|}
\hline 1QS 5,1 & $\begin{array}{l}\text { This is the rule for the men } \\
\text { of the community. }\end{array}$ & זות הסרכ לאנשי היחד \\
\hline Isa 58,7 & $\begin{array}{l}\text { You shall not hide yourself from } \\
\text { your own flesh. }\end{array}$ & 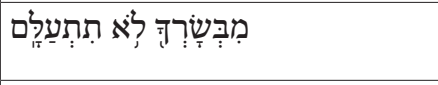 \\
\hline Acts 4,34 & $\begin{array}{l}\text { There was not a needy person } \\
\text { among them. }\end{array}$ & 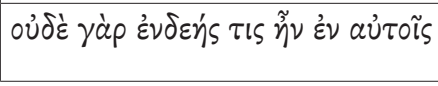 \\
\hline
\end{tabular}




\section{The composition of the community and missionary pattern}

The nature of the community's composition indicates how the parting of the ways is still at stake and the invitation to participate in the life of the Way is directed to all humanity beginning with the Jews and extending to the Gentiles.

\subsection{The presence of the Pharisees}

The Pharisees gain Luke's interest as he refers to them 26 times in his gospel and 7 times in the Acts. In comparison, they are referred to on 29 occasions in Mt and 19 in Jn. The multifaced presentation of this group is striking, as seen in the following four characteristics:

\section{(1) Negative}

Jesus criticizes them for having rejected the purpose of God for them (Lk 7,30), being hypocrites both in prayer and deeds (Lk 12,1; 18,10) and greedy for money (Lk 16,14). Thus, he expresses threefold woes against them ( $\operatorname{Lk} 11,42.43 .44)$.

\section{(2) Positive}

Only in Luke's gospel and in spite of Jesus' constant critique, the Pharisees invite him different times to dine with them ( $\operatorname{Lk} 7,36 ; 11,37 ; 14,1)$, thus they would like to hear from him ( $\operatorname{Lk} 11,53 ; 17,20)$.

\section{(3) Absence at the trial sequences}

They try to prevent Jesus' death by proposing him to depart from Galilee (Lk 13,31), they disagree with the Messianic greeting of Jesus as the Blessed King (Lk 19,39). Moreover, they are not mentioned either at Jesus' trial as in other gospels ( $\mathrm{Lk} 22,66$; Mt 27,66; Mk 12,13) or in process against the apostles in the Acts (Acts 4,1; 5,17).

\section{(4) Members of the community of believers}

They are omitted in the list of the accusers at the trial; however, they are mentioned as members of the community (Acts 15,5). Moreover, Gamaliel steps in to defend the apostles (Acts 5,34) and Paul becomes a main missionary (Acts 23,6). 


\subsection{The presence of God-fearers and of the Gentiles}

On the other hand, Luke points at the presence of the Jewish sympathizing God-fearers (Acts 10,2.22; 13,16.26) and the Gentiles. The participation of the Gentiles is envisioned and prepared for already by the formation of the corpus of 72 disciples (Lk 10,1) and by the Jews from Diaspora present at the Pentecost (Acts 2,5). There is sympathy of some Gentiles towards the Jewish religiosity ( $\operatorname{Lk} 7,4-5$; Acts 10,1-2); however, the participation is divinely confirmed upon those who fear God and work righteousness (Acts 10,35). These Gentiles have received the Holy Spirit (Acts 10,45) and accepted the Word of God (Acts 11,1; 13,48). While the initiative is that of God who has opened the door of faith (Acts 14,27; 15,3) and is forming a people for his name (Acts 15,14), the community has also undertaken the process of admitting the Gentiles to their community (Acts 15,17).

\subsection{Continuous pattern of the missionary activity}

Luke, indicating Paul's missionary pattern ${ }^{1}$ sent first to the Jews only then to the Gentiles, shows how God is faithful towards his people, inviting them to fulfill their place of primacy in God's plan to restore his people by the inclusion of all humanity. In this Luke does not seem to have such a negative opinion about the Jews, as scholars such as Alfred Loisy (1920) might think, although, as Jacob Jervell (1965) shows, the division is introduced into the people of God due to the lack of faith of one part of Israel. However, the mission to the Gentiles is not caused by Israel's disbelief, but rather by the faith of a part of Israel, since it is the believing Israel that begins the Gentile mission in order to extend the blessing of Abraham's covenant. (Lohfink 1975, 47-62) Here Jacques Dupont is right in affirming that God has only one elected people and the inclusion of the Gentiles cannot be hindered by Israel's rejection (1984).

The shift of the invitation to become God's people to the Gentiles had already been envisioned since the Lord had already foretold it by the prophet Isaiah: »I have made you a light for the Gentiles, that you may

1 For Paul's missionary activity in the communion with the Church in Jerusalem see Maksimilijan Matjaž (2019, 179-184). 
bring salvation to the ends of the earth." (Acts 13,47; Isa 49,6) This mission and its opposition meet in every place where Paul enters. Thus, facing the opposition of the Jews in Corinth, Paul says: »Your blood be on your own heads! I am innocent. From now on I will go to the Gentiles." (Acts 18,6) The opposition that Paul faces comes from both sides; for this reason, he is given God's consolation: »I will deliver you from the people of the Jews, and from other nations; to whom I send you.» (Acts 26,16-17)

Even in Rome, Paul's mission is addressed both to the Jews and the Gentiles (Acts 28,23-24), however, his message is not taken seriously by all, therefore, Paul concludes: »Let it be known to you therefore, that this salvation of God has been sent to the Gentiles; they will also listen." (Acts 28,28) However, this affirmation does not mean the rejection of Israel, since it follows the aforementioned missionary pattern; but rather, it invokes the prophetic legacy of a call to conversion. Luke takes from the tradition of the Jewish Scriptures to show how God's plan of salvation for all humanity has been enacted in Jesus and his followers, even though it includes a growing division of the people.

\section{Rootedness in the tradition of the Jewish Scriptures}

In spite of different approaches, scholars have demonstrated how Luke is at home in the Jewish Scriptures and how he uses the Scriptures to support the claim that the community of the believers is the enactment of God's plan for both Israel and humanity.

\subsection{Redactional approach}

Scholars such as Traugott Holtz (1968) and Martin Rese (1969) addressed some redactional-critical questions regarding the text and the relationship between tradition and composition. Holtz's approach demonstrates that while the LXX text of the Twelve prophets, Isaiah, and the Psalms is significant for Luke, Luke shows little regard for the narrative of Genesis and Exodus. Rese, on the other hand, provides a categorisation for the different uses of quotations: hermeneutic, typological, and scriptural proofs or allusions in terms of promise-fulfilment that all serve Luke's theological and Christological concern. 


\subsection{Literary approach: typology}

Here the discussion does not simply involve proof-from-prophecy citations, but also draws on typological allusions that point to the unity and divine guidance of the history of salvation. The figures and events of the OT foreshadow the story of Jesus and his followers. Rebecca Denova (1997) endeavours to show how Luke, using the prophetic tradition, designs his structure of the narrative and demonstrates the fulfilment of the promises made to Israel. In this field of research Thomas Brodie's study points to an Elijah-Elisha typology (2014), whereas Robert Brawley sees an Abrahamic one (1999). In brief, the Elijah-Elisha typology (Lk 4, 25-27; 7,11-17) will be rejected by Jesus (Lk 9,54-55) and replaced by general prophetic expectation (Lk 13,34-35). While a patriarchal and Abrahamic typology structures the first volume (Lk 1,55.73; 3,8; 13,16.38; 16,22; 19,9; $20,37 ; 24,50-51)$, a Davidic one will also have an important role through its connection with suffering ( $\operatorname{Lk} 9,22$; Acts 2,37; 13,35). Most recently studies on Isaianic Servant typology have been elaborated as Rouven Genz, who believes that Jesus' followers can be rightly addressed as "servants of the Servant« $(2015,413)$.

\subsection{Isaianic New Exodus}

Jindřich Mánek (1957) has uncovered another typological dimension that may have an apologetic aim. This is not to be seen only in terms of the Roman religio licita but moreover, as a demonstration that the community has been envisioned in God's plan which also includes the acceptance of the members coming from the Gentile world. While the Isaianic New Exodus portrays the return of Israelites to their homes with the acceptance of the Gentiles as a secondary members of the people of God, Luke's two-volume corpus aims to demonstrate that God's plan is to form a people without distinction for those who fear him (Acts 10,34-35; 15,8-9; 18,10).

The monograph of David Pao, Acts and the Isaianic New Exodus, focusing on this restoration pattern, is enlightening. Pao reconsiders the compositional and theological issues that have been missing in scholarly contributions prior to his own. Pao endeavours to explain Luke's hermeneutical 
framing in reformulating the foundational story of Exodus reshaped in the Isaianic corpus.

Pao shows that Isaiah's New Exodus functions not merely as an apologetic proof-from-prophecy, but as a frame for the entire Lukan literary work. The citation of Isa 40,3-5 in Luke 3,4-6 provides a hermeneutical key for Luke-Acts. Furthermore, the reference to »the Way« identifies the movement and the community. The Lukan insistence on "all flesh will see God's salvation" integrates both the Gospel and Acts under the Isaianic New Exodus, according to which the Gentiles can also be included in the redefined people of God. Both the Isaianic themes and »the Way« terminology argue in favour of understanding the early Christian community as the true heirs of the Israelite traditions. The exodus terminology in Isa $40-55$ which is evoked by Luke is an attempt to redefine the identity of the people of God and indicates both continuity and discontinuity. $(2000,69)$

Holly Beers recently presented her analysis of the Lukan narrative based upon typological and intertextual hermeneutic assumptions. She adopts Searle's Speech Act Theory, as she claims that the text is the speech act of the author. Beers $(2015,30)$ is convinced that the use of Isaiah in LukeActs may be explained through Speech Act Theory, claiming:

Luke's illocutionary act in using Isaianic servant material is to portray Jesus and the disciples as embodying the servant vocation [...]. The assumed perlocutionary effect is first for the implied reader/ hearer to be persuaded of this identification and second, to recognize her place as a follower of Jesus.

There are three corollaries to this reading. First, the motif of the Servant enables Beers first to expose the plot of the Isaianic narrative: the choosing of the Servant (42-48), the expansion and climax of the Servants' task (49-53), the vindication of the Servant by the formation of the community of the servants (54-60) that are appraised and vindicated (61-66). Second, the servant typology is already attested to in the second temple period. Third, while the Gospel centres on Jesus preparing his disciples for the task of servants, Acts focuses on the disciples in their role as servants. Thus, the Isaianic Servant figure is the very heart of Jesus and his followers who continue his work. 


\section{Close reading}

The narrative plot might seem a "tragic story of Israel (Tannehill 1985) or as a "pathos-tragedy« with a »call to conversion" (Tiede 1986), as Luke's narrative introduces the reader giving high expectations. However, despite the harsh prophetic words at the end, it seems that an open-ended conclusion gives the reader the freedom either to hear, to believe, and to convert or to decline the offer of conversion and salvation. Here I would like to present (1) some textual particularities that set the Lukan story in continuity within the history of salvation, and (2) the narrative of Acts 2-3 as the cornerstone of the community of the believers that will extend Jesus' message to the world.

\subsection{Use of Scriptures}

Luke gets his inspiration from the LXX, thus, these Scriptures indicate both the content and style of Luke's story. Yet, Luke does set his story in continuity with the biblical account not only by his use of Semitisms (e.g. Lk 1,5:

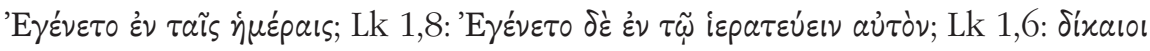

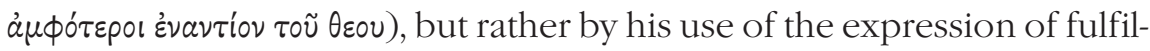
ment or accomplishment in $\operatorname{Lk} 1,1$ and also later in the narrative ( $\operatorname{Lk} 4,21$; 22,27; 24,44; Acts 1,6; 3,18). However, Luke's story does not mean a new stage of history, not even as a simply hermeneutical pattern of prophe$c y$-fulfilment, but rather, as a continuation of salvation-historical account as Joel Green notices (1997). The God who has been working redemptively still is, now, and especially, in Jesus. While Green points to the typological reading of the Abrahamic tradition (e.g. do not be afraid: Gen 15,1; Lk 1,13.30; righteousness: Gen 15,6; Lk 1,6; barrenness: Gen 16,1; Lk 1,7; conceiving and bearing a son: Gen 16,11-12; Lk 1,31-32), ${ }^{2}$ Timothy Johnson $(1981,37-70)$ invites readers to consider a more general prophetic tradition (e.g. Nazarite vow: Judg 13,5; Lk 1,15; 7,33; joy and gladness: Isa 12,6; 25,9; Lk 1,14; 3,2; filled with the Holy Spirit: Jer 1,5; Isa 61,1; Lk 1,15; God's visit of the people).

2 This typology was important also in the Qumran community as demonstrated by Samo Skralovnik (2018, 707-720). 
Here I will examine the textual elements of words and redactional arrangements, both of which evoke Isaiah's New Exodus. This pattern can be categorized in five thematic sets: (1) God's sovereignty; (2) the people of God; (3) the release of captives; (4) the response to God; (5) the universal call to salvation.

These thematic sets form the "cave of resonant signification", as John Hollander $(1981,65)$ would call it, or as Ziva Ben-Porat would say, they are "allusion markers" $(1978,107-111)$. These criteria create a thematic sieve to read the textual allusions by which Luke's text evokes Isaiah's.

\subsection{Isaianic New Exodus Allusions in Lk 1-2 and Acts 2-3}

The Isaianic New Exodus represents an important literary model for Luke, as mentioned above. Here I want to offer just a few examples at the opening of the Luke's gospel before proceeding to the narrative of Acts.

\section{Lk 1-2}

Luke manages to intertwine the figure of John and Jesus in a set of two parallel storylines that move from promise towards fulfilment and final praise of God. I want to ponder only a few significant words that evoke Isaiah's text.

(1) The reference to $\pi a p \theta \varepsilon$ v́ $о$ s "virgin" mentioned twice in Lk 1,27 defends the divine intervention at the present moment of history by evoking Isaianic text that foretells the coming of the Messianic king and Messianic times (Isa 7,14; 62,5). The stress here is not on this word which also occurs later in the narrative (Acts 21,9), but rather on the divine power that surpasses nature as it is manifested on the feast of Pentecost and in the subsequent narrative (Acts 4,31).

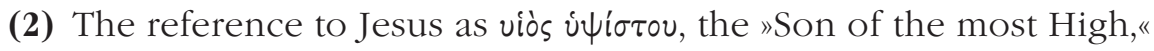
in Lk 1,32 evokes a similar Messianic appellative in Isa 9,5. Moreover, the reference to God, the Most High, who abides not in human-made houses but both on high and in the hearts of the lowly (Isa 57,15; 66,1-2), gives Luke the chance to dismiss the understanding of the temple as the divine abode (Acts 7,48; 16,17) in order to show that God through his Spirit abides in the hearts of the believers (Acts 5,3). 


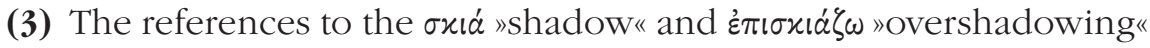
display the presence and the power of its owner, i.e. standing in the shadow of a god could bestow special power (Horst 1977, 206-210). Thus, a shadow symbolizes both the greatness of his reign (Isa 4,6) and man's transience (Isa 9,1), but mostly the divine protection of his people (Isa 51,16). Luke adopts this figurative language (Lk 1,35.51; Acts 5,13) to demonstrate God's power to restore his people.

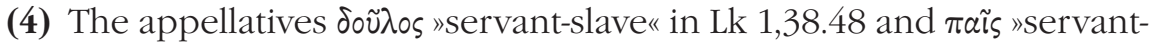
-boy« in Lk 1,54 evoke Isaiah's narrative (Isa 41,1-2; 44,8-9; 49,3; 56,6) and become titles for Jesus (Acts 3,13) and his followers (Acts 4,29).

(5) The events of the eschatological turn in the power of the Holy Spirit

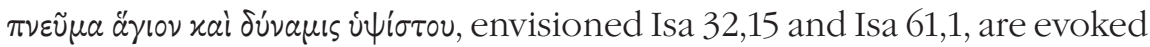
as realised in Lukan narrative both for the individuals ( $\operatorname{Lk} 1,35.41 .67$ ) and for the community of believers (Acts 2,4.33).

(6) Moreover, the $\phi \tilde{\omega} \varsigma \dot{\varepsilon} \theta \nu \tilde{\omega} \nu » l i g h t$ to the nations of Isa 42,$6 ; 49,6$ is set at three important points of the narrative. Whereas at the beginning the reference is applied to Jesus ( $\operatorname{Lk} 2,32$ ) and in the final part (Acts 26,23) the reference is also related to Jesus, at the pivot of the story in Acts (Acts 13,47) the reference is applied to the mission, evangelisation of Christ to the Gentiles.

As the reader turns the page to Luke's second volume, the plot picks up right where Luke has ended the gospel. Both the episodes of Ascension and Pentecost confirm Jesus' kingship; however, this should be proclaimed all over the world. The Spirit, symbolically depicted as water (Isa 44,3) and fire $(5,24)$, empowers prophetic mission $(61,1)$ and the power to witness to the Lord (Lk 4,1; Acts 1,8). (Beers 2015, 128-133)

\section{Acts 2-3}

Jesus commissioning his disciples to the universal mission in Acts 1,8, rooted in Isaiah's tradition (Isa 48,20; 49,6; 62,11), continues the string of Luke's programmatic statements (Lk 4,16-30; 24,44-49; 13,46-47; 28,25-28) which incorporate the themes of rejection (Isa 6, 9-10; Acts 28,25-28) and the inclusion of the Gentiles (Isa 49,6; Acts 13,46-47) in order to emphasize 
the continuity and discontinuity of the Christian community (Pao 2000, 109-110).

The Pentecost represents the fulfilment of the promises regarding the coming of the Spirit (Lk 24,49; Acts 1,4-5.8). The event hints at the mission both to the Jews and to the Gentiles. The centripetal and centrifugal movements echo Isaiah when he recounts the return of the exiles (Isa 45,20), the proclamation to the nations (Isa 45,22), and the pilgrimage of the nations (Isa 2,1-5). Despite a clear Jerusalem-centred perspective, the universal kingship of Jesus is defended, building up a new identity, empowered by the Spirit. (Thompson 2008, 68-70)

The sequence of the event-speech follows a similar pattern regarding Jesus' mission as presented at the beginning of Luke's Gospel (Tannehill 1990, 29). In both cases we notice that (1) the coming of the Spirit is related to prayer (Lk 4,18; Acts 2,17-18); (2) the scriptural quotation made in both speeches characterizes the mission as a "release $(\operatorname{Lk} 4,18)$ and »release of sins« (Acts 2,38); (3) the speech is followed by rejection (Lk 4; Acts 4-5).

Peter explains the bestowal of the Spirit by referring to prophetic words (Acts 2,17-21; LXX Joel 3,1-5). Textual hints in 2,14 (»all those dwelling in Jerusalem»), 2,36 (»the whole house of Israel«) and 2,39 ("all those far off «) refer to all the Jews, both to those who reside in Jerusalem and to those, scattered throughout the world, but now present in Jerusalem. However, this is a proleptic anticipation of the universal mission, since the Gospel is first addressed to all Israel, scattered throughout the world, and, second, it also addresses the Gentile inhabitants of the Jewish Diaspora. The bestowal of the Holy Spirit represents the eschatological realisation of Joel's promise. In fact, Peter twice underscores the eschatological tone of the prophecy (LXX Joel 3,1[2]: afterward [those days]; Acts 2,17-18: in the last days). The discourse marked by the »latter days« evokes Isaiah's view, indicating that the Lord's Law and His Word of judgment are valid for both Israel and all the nations (Isa 2,2-4). (Pao 2000, 156-159) Likewise, the gift of the Spirit bestowed »upon every flesh" (Joel 3,1; Acts 2,17) suggests an eschatological and universal dimension (Lk 3.6; Acts 2,39 [Isa 40,5; 49,26]; Acts 13,47 [Isa 49,6]) and enables universal comprehension. (McWhirter 2013, 51) 
The healing account in Acts 3 is significant, since it both echoes Jesus' healing pattern (Lk 5,17-26) as a realisation of Isaianic hopes (Lk 7,22 [Isa $35,6 ; 55,12])$ and indicates the competence of the apostles, as it is later confirmed in the mission of Paul (Acts 14,8-13). Healing and teaching in Jesus' name (Acts 3,6) differ from the magic-like incantations and have an important social and theological function, reinserting the healed person into the community and demonstrating the Spirit-empowered mission. (Marguerat 2003, 101-103; Nielsen 1987, 170-172) Peter takes the crowd's amazement (Acts 3,10ff.) as an opportunity to explain the healing in the light of the history of salvation that climaxes in Christ. A change of mindset as a return to God is necessary for the realisation of the eschatological times envisioned in three stages: (1) the remission of sins $(3,19),(2)$ the arrival of the Messiah who brings refreshment $(3,20)$, and (3) the restoration of all things $(3,21)$. The future blessing as the eschatological restoration in Christ is addressed first to the Jews as the heirs of the promises and then to the Gentiles (3,25-26). This same pattern, i.e. the Word of God addressed first to the Jews and then to the Gentiles, is also echoed in the mission of Paul found later in the narrative (13,46; 18,5-6; 28,23-28). (Hansen 1998, 299-300)

The narrative plot in Acts 3-5 portrays how the apostles, in spite of the growing conflict with the official religious authorities, give testimony to and present the kerygma, i.e. God's plan of salvation in Christ, by explaining Jesus' name. Linking it to other Christological titles such as: servant, holy, righteous, leader to life (Acts 3,13-15), Peter evokes the figure of the Isaianic Servant (see Isa 43-53). (Goulder 2000, 72-73) Moreover, by applying the Old Testament's motif of »cornerstone« to Jesus (Ps 117,22; Isa 28,16; Acts 4,11), Peter stresses the universal and soteriological meaning of the name (Acts 4,10-11). The fact that Jesus represents the foundation of the community's life and salvation is later confirmed as Peter acclaims Jesus as the "forerunner and saviour, " that is as the one who leads to life and guides towards salvation (Acts 5,31; Hebr 2,10), and nevertheless, as the one who judges the living and the dead (Acts 10,42; 17,31). (Eskola 2015) 


\subsection{Isaianic New Exodus Allusions in the first summary account (Acts 2,42-47)}

The narrative plot in Acts 3-5 shows God's plan of salvation in Christ is not for the condemnation of the Jews, but rather as a turning point for conversion and salvation through hearing of the proclamation (Acts 10,44). The identity of the community is being depicted in a set of three summary narrative accounts (Acts 2,42-47; 4,32-35; 5,12-16).

The core of the community is the theme of unity as it encapsuled in Acts 2,42 , since they are (1) united in hearing to the apostles' teaching, they (2) break bread and enjoy fellowship at table and (3) they nourish this unity by praying together.

(1) First of all, the community is characterized by unity (Acts 2,44.46[47]) representing a realisation of the initial hopes of restoration (Acts 1,6). If unity becomes a characterizing trait of the community, this is due to God's work $(2,47)$. This fact evokes the Isaianic process of restoration, primarily ascribed to the Lord by showing his arm on behalf of his remnant (Isa 11,11) and by forming his servant as a hearing disciple $(50,4)$. The theme of the restoration of unity is further portrayed as the Lord gathers his flock $(40,10-11)$ and summons his servants from the ends of the earth (41,8-9) and redeems his people (43,1-9). While in Isaiah the Gentiles are dominated by the Jews (Isa 49,7), in Acts the relationship between the Gentiles and the Jews is marked by equality before God (Acts 10,34). This new understanding is foreshadowed in this summary in Acts by the institution of the house/household, which enhances the possibility of overcoming social-religious boundaries $(2,46)$, as the house represents the setting of the missionary activity (Lk 10,5; Acts 10,27). (Malherbe 1977; Beale 2004; Gehring 2004)

(2) Table-fellowship as an expression of unity $(2,42)$, enables kinfolk relationships among members, implying some form of common possession achieved by selling goods and distributing proceeds to the needy $(2,45)$. However, the main focus is on unity, as Alan Thompson $(2008,67)$ concludes: 
The focus is not primarily on a 'community of goods' but on meeting needs as an expression of the unity of the community in common allegiance to the Lord Jesus.

Moreover, table-fellowship means sharing meals which echoes the Isaianic New Exodus in three ways: (1) by reinterpreting Jubilee tradition in terms of loosening the chains of injustice, sharing bread and house with the outcast (Isa 58,6-7), and (2) by realising eschatological hopes through the empowerment of the Spirit $(61,1)$ and $(3)$ by interpreting the welcoming of homes in universal terms $(58,7)$. The prophetic role of the restoration of social justice, meal sharing with universal openness announced in the Nazareth episode ( $\operatorname{Lk} 4,14-21$ ), now passes over to the community (cf. Acts 2,38-39). (Gurtner 2013, 140)

(3) The reference to prayer (Acts 2,42.47) characterizing the community implies the recognition of the primordial authority of God and the experience of salvation ( $\operatorname{Lk} 1,58$; Acts 2,11). Prayer has the purpose of forming and preserving unity (Acts 1,14ff.) especially in periods of trial (4,24ff.). The image of God who is both omniscient, i.e., knowing the hearts of man and a mighty creator of heaven and earth evokes the theme of prayer in Isaiah. God knows about the Assyrian treat towards Jerusalem and promises a confront to the people (Isa 37,6), thus also the king Hezekiah in a time of distress recognizes god as the creator (Isa 37,16). Later Hezekiah utters another prayer of gratitude for salvation with expressions of praise and joy (Isa 38,18-20). In fact, God's creative power enables both the exodus of the redeemed people and its joyful response (Isa 51,9-11).

Luke's insistent reference to unity hints at the Isaianic process of restoration with universal repercussions (Isa 11,6-11; 43,5-8). While the apostles enact the role of the Servant $(50,4)$, the community responds by taking care of social needs (58,6-7) and true worship in prayer (38,18-19; 58,1314). The blessing of the community, although stemming from God (51,911 ), depends on the community's adherence to the teaching $(50,4)$ and social sensitivity $(58,6-9)$. While the summaries reveal that the community enjoys God's blessing and is God's work, the subsequent summary statements, which speak about the growth in the number of believers as a blessing bestowed on the community, reveal God's power through 
which the community spreads its teaching $(4,31)$ even in the face of fierce opposition. (Block 1989, 48)

6,1: $\quad$ The disciples were increasing in number

6,7: The word of God grows, the number of the disciples increases greatly

12,24: The word of the Lord grows and multiplies.

19,20: The word of the Lord grows mightily and prevails.

While the verbal pair $\eta \dot{\xi} \xi \dot{\eta} \theta \eta \sigma a \nu$ xal $\dot{\varepsilon} \pi \lambda \eta \theta \dot{v} \theta \eta$ бav evokes the exodus from

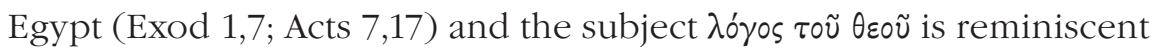
of Isaiah in depicting God's action for his people (Isa 51,16), the Isaianic New Exodus is evoked in a summary statement at the conclusion of the Jerusalem part of Lukan narrative in Acts 9,31 by the terminology of: peace (Isa 54,13), building (54,14), fear of the Lord (Isa 51,12), and comfort of the Holy Spirit (Isa 61,1-2). The fact that the community is restored in peace through Jerusalem-Samaria not only evokes the reconciliation of Ephraim and Judah in Isa 11,13 but also enables the next step of the reconciliation and restoration of humanity through the mission to the ends of the world (Acts 1,8).

\subsection{Apologetic (Apologia)}

The community does not break with tradition but reinterprets it within the history of salvation, and this is a necessary process for the growth of the community through time. Due to the constant rejection by the Jews, the Christians gathered in Christ's name are obliged to form a proper communal expression of being the people of God. (Twelftree 2009, 52-83; Johnson 1979, 91-94) Moreover, due to God's intervention the community extends the borders of the missionary proclamation into the Gentile world and discovers step by step that God forms a people for his name that also includes Gentiles (Acts 15,14) (Dahl 1958, 319-327). This process is indicated by the text itself. Thus Joel Green $(1996,290)$ observes how the community's scriptures reveal a twofold continuation with Jesus and tradition:

Vis-à-vis the intertextual reverberations of the Lucan narrative with the LXX (i.e., external repetition), Luke inscribes himself in 
scriptural tradition, showing his debt to this previous story, and inviting his auditors to hear in this narrative the resounding continuation of that story. Vis-à-vis intertextual reverberations within Luke-Acts (i.e., internal repetition), Luke shows the great extent to which the story of the early church is inscribed into the story of Jesus, all as continuation of the divine story of redemption.

However, this rootedness in the history of the people of God also reveals the apologetic aim of Acts, (Alexander 1999, 16-19) as it addresses both (1) Greco-Romans and (2) Jews.

(1) Concerning the first, Gregory Sterling $(1992,384)$ points out that the literary genre of Luke-Acts is an apologetic historiography with the aim of defending the Church as consisting of God's people who should ensure that Israel is given the status of religio licita by the Romans.

(2) Concerning the relationship with the Jews, there is a socio-rhetorical reflection of the Lukan community with regard to Jewish-Christian conflict (Gager 2007, 31-35) in its persuasion of God-fearers to participate fully in Christianity (Tyson 1992). The question of faith and membership of the people of God in terms of salvation moves from exclusion towards the eschatological inclusion of the Jews (Rom 11,26; Isa 59,20-21). While Bart Koet (1989, 119-136) interprets the situation of Israel in terms of misperception (Acts 28,28; Isa 6,9-10) and John O'Neill (1970, 71-115) claims that their rejection is not final in God's purpose, the nascent Church, consisting of the Jews and the Gentiles, hopes that at the end all Israel will be included. (Ravens 1995, 204-211)

\subsection{Moral dimension}

The restoration of the people as the result of fellowship with Christ requires the renewal of relationships within the community. To put it in a nutshell, the effectiveness of the blessing implies: (1) a humble stance towards the teaching of God conveyed by the apostles; (2) the sharing of possessions; and (3) sensitivity for the sick and outcasts. Conversion is not a demonstration of a human "virtuous decision" but the humble acceptance of the gift of the Spirit who purifies as fire and renews the 
perception of human hearts (cf. Isa 4,4). In fact, this lies at the very heart of the book of Isaiah as Ronald Clements $(1985,102)$ affirms:

The theme of Israel's blindness and deafness, understood in a metaphorical and spiritual sense, is clearly of central importance to Isa 40-55.

\section{Conclusion}

Sometimes it is difficult to set right boundaries that are not too loose neither too strict. Luke's narrative artistry, Luke's whispering voice combined with the echo of Isaiah tries to convince his reader to recognize both the divine action on behalf of this community that stems from the Jewish tradition and the invitation to extend this blessing by forming kindship, i.e., family-like relationships, first within our communities and then with the persons around us. Positive reception of the tradition enables one to perceive how the Spirit invites the community to embrace new things and bring God's kingship to the ends of the earth.

\section{References}

Alexander, Loveday C. A. 1999. The Acts of the Apostles as an Apologetic Text. In: Mark Edwards, Martin Goodman and Simon R. F. Price, eds. Apologetics in the Roman Empire, 15-44. London: Clarendon Press.

Beale, Gregory K. 2004. The Temple and the Church's Mission: A Biblical Theology of the Dwelling Place of God. Vol. 17, New Studies in Biblical Theology. Downers Grove (IL): InterVarsity Press.

Beers, Holly. 2015. The Followers of Jesus as the "Servant": Luke's Model from Isaiah for the Disciples in Luke-Acts. Vol. 535, Library of New Testament Studies. London: Bloomsbury Publishing .

Ben-Porat, Ziva. 1978. The Poetics of Literary Allusion. A Journal for Descriptive Poetics and Theory of Literature 1: 105-128.
Block, Daniel I. 1989. The Prophet of the Spirit: The Use of Rwh in the Book of Ezekiel. Journal of Evangelical Theological Society 32/1: 27-49

Boyarin, Daniel. 2003. Semantic Differences; or, »Judaism«/»Christianity«. In: Adam H. Becker and Annette Yoshiko Reed, eds. The Ways that Never Parted: Jews and Christians in Late Antiquity and the Early Middle Ages, 65-85. Tübingen: Mohr Siebeck.

Brawley, Robert L. 1999. Abrahamic Covenant Traditions and the Characterization of God in Luke-Acts. In: Joseph Verheyden, ed. The Unity of Luke-Acts, 109-132. Leuven: Peeters. 
Brodie, Thomas L. 2014. Luke's use of the Elijah-Elaisha Narrative. In: John S. Kloppenborg and Jozef Verheyden, eds. The Elijah-Elisha narrative in the Composition of Luke, 6-29. London etc.: Bloomsbury.

Clements, Ronald E. 1985. Beyond TraditionHistory: Deutero-Isaianic Development of First Isaiah's Themes. Journal for the Study of the Old Testament 31: 95-113.

Dahl, Nils Alstrup. 1958. A People for his Name. New Testament Studies 4: 319-327

Denova, Rebecca I. 1997. The Things Accomplished Among Us: Prophetic Tradition in the Structural Pattern of Luke-Acts. Vol. 141, Journal for the Study of the New Testament Supplement. Sheffield: Academic Press.

Dupont, Jacques O. S. B. 1984. Teologia della Chiesa negli Atti degli Apostoli. Bologna: EDB.

Eskola, Timo. 2015. A Narrative Theology of the New Testament: Exploring the Metanarrative of Exile and Restoration. Vol. 350, Wissenschaftiche Untersuchungen zum Neuen Testament. Tübingen: Mohr Siebeck.

Gager, John G. 2007. Where Does Luke's AntiJudaism Come From? Annali di Storia dell'Esegesi 24/1: 31-35.

Gehring, Roger W. 2004. House Church and Mission: The Importance of Household Structures in Early Christianity. Peabody, MA: Hendrickson.

Genz, Rouven. 2015. Jesaja 53 als theologische Mitte der Apostelgeschichte: Studien zu ihrer Christologie und Ekklesiologie im Anschluss an Apg 8,26-40. Vol. 2.398, Wissenschaftliche Untersuchungen zum Neuen Testament. Tübingen: Mohr Siebeck.

Goulder, Michael D. 2000. The Anointed. In: J. L. North and Steve Moyise, eds. The Old Testament in the New Testament. Essays in Honour of J.L. North, 66-74. Sheffield: Academic Press.
Green, Joel B. 1996. Internal Repetition in Luke-Acts: Contemporary Narratology and Lucan Historiography. In: III Witherington B., ed. History, Literature, and Society in the Book of Acts, 283-299. Cambridge: Cambridge University Press.

- - -. 1997. The Gospel of Luke, New International Commentary on the New Testament. Grand Rapids (MI) Eerdmans.

Gurtner, Daniel M. 2013. Luke's Isaianic Jubilee. In: Daniel M. Gurtner, Benjamin L. Gladd and Gregory K. Beale, eds. From Creation to New Creation: Biblical Theology and Exegesis. Essays in Honor of G. K. Beale, 123-146. Peabody MA: Hendrickson.

Hansen, Walter G. 1998. The Preaching and Defence of Paul. In: I. Howard Marshall and David Peterson, eds. Witness to the Gospel: The Theology of Acts, 295-324. Grand Rapids (MI): Eerdmans.

Hollander, John. 1981. The Figure of Echo: A Mode of Allusion in Milton and After. Berkeley: University of California.

Holtz, Traugott. 1968. Untersuchungen über die alttestamentliche Zitate bei Lukas. Vol. 104, Texte und Untersuchungen zur Geschichte der altchristlichen Literatur Leipzig: Akademie Verlag.

Horst, Pieter Willem van der. 1977. Peter's Shadow: The Religio-Historical Background of Acts V. 15. New Testament Studies 23/2: 204-212. https://doi.org/10.1017/s0028688500008912

Jervell, Jacob Stephan. 1965. Das gespaltene Israel und die Heidenvölker: Zur Motivierung des Heidenmission in der Apostelgeschichte. Studia Theologica 19: 68-96. https://doi.org/10.1080/00393386508599867

Johnson, Luke Timothy. 1979. On Finding the Lukan Community: A Cautious Cautionary Essay. Society of Biblical Literature Seminar Papers 1: 87-100.

- - -. 1981. Sharing Possessions: Mandate and Symbol of Faith. Philadelphia: Fortress. 
Koet, Bart J. 1989. Five Studies on Interpretation of Scripture in LukeActs. Leuven: University Press.

Lohfink, Gerhard. 1975. Die Sammlung Israels: Eine Untersuchung zur lukanischen Ekklesiologie. Vol. 39, Studien zum Alten und Neuen Testament. München: Kösel.

Loisy, Alfred Firmin. 1920. Les actes des apôtres. Paris: Nourry.

Malherbe, Abraham J. 1977. Social Aspects of Early Christianity. Philadelphia: Fortress Press.

Mánek, Jindřich. 1957. The New Exodus in the Books of Luke. Novum Testamentum 2: 8-23.

Marguerat, Daniel. 2003. Magic and Miracle in the Acts of the Apostles. In: Todd E. Klutz, ed. Magic in the Biblical World: From the Rod of Aaron to the Ring of Solomon, 100-124. London: Sheffield Academic Press.

Matjaž, Maksimilijan. 2019. Občestvo kljub različnosti: Pavlovo razumevanje koinonie v Pismu Galačanom (Gal 2,9). Edinost in dialog 74/1: 175-193. https://doi.org/10.34291/edinost/74/matjaz

McWhirter, Jocelyn. 2013. Rejected Prophets: Jesus and His Witnesses in Luke-Acts. Minneapolis MN: Fortress.

Nielsen, Helge Kjaer. 1987. Heilung und Verkündigung: Das Verständnis der Heilung und ihres Verhältnisses zur Verkündigung bei Jesus und in der ältesten Kirche. Vol. 22, Acta Theologica Danica. Leiden: Brill.

O'Neill, John C. 1970. The Theology of Acts in its Historical Setting. Second revised and supplemented ed. London: SPCK.

Pao, David W. 2000. Acts and the Isaianic New Exodus. Vol. II.130, Wissenschaftliche Untersuchungen zum Neuen Testament. Tübingen: Mohr Siebeck.
Ravens, David. 1995. Luke and the Restoration of Israel. Vol. 119, Journal for the Study of the New Testament Supplement. Sheffield: Academic Press.

Rese, Martin. 1969. Alttestamentliche Motive in der Christologie des Lukas. Vol. 1, Studien zum Neuen Testament. Gütersloh: Mohn.

Skralovnik, Samo. 2018. Podoba Abrahama v kumranski apokrifni Genezi (1QapGen). Bogoslovni vestnik 78/3: 707-720.

Sterling, Gregory E. 1992. Historiography and Self-Definition: Josephos, Luke-Acts and Apologetic Historiography. Vol. 64, Novum Testamentum Supplements. Leiden: Brill.

Tannehill, Robert C. 1985. Israel in Luke-Acts. A Tragic Story. Journal of Biblical Literature 104/1: 69-85. https://doi.org/10.2307/3260594

- - -. 1990. The Narrative Unity of LukeActs: A Literary Interpretation. Vol. 2, The Acts of the Apostles. Philadelphia: Fortress Press.

Thompson, J. Alan. 2008. One Lord, One People. The Unity of the Church in Acts in its Literary Setting. Vol. 359, Library of New Testament Studies. London: T \& T Clark.

Tiede, David Lenz. 1986. "Glory to Thy People, Israel": Luke-Acts and the Jews. Society of Biblical Literature Seminar Papers 25: 142-151.

Twelftree, Graham Hedly. 2009. People of the Spirit: Exploring Luke's View of the Church. Grand Rapids (MI): Baker Academic; Society for Promoting Christian Knowledge.

Tyson, Joseph B. 1992. Images of Judaism in Luke-Acts. Columbia (S.C.): University of South Carolina Press. 